\title{
An Effect of Biosolar-Water Emulsion on Small Marine Diesel Engine
}

\author{
Beny Cahyono*, Taufik Fajar Nugroho, Tony Bambang Musriyadi \\ Sepuluh Nopember Institute of Technology (ITS) \\ Indonesia \\ *Corresponding author's email: cak_beny [AT] yahoo.com
}

\begin{abstract}
This study aims to analyze the effect of water/biosolar emulsion fuel on the performance of engine diesel used in small capacity diesel engines. The fuel used is a mixture of biosolar $20 \%$ which is added 10\% and 15\% water (b20,WDE 10\%, WDE 15\%) which will be compared with dexlite fuel and biodiesel $20 \%$ (b20). Measurement of engine performance with various fuels was carried out in accordance with IMO marine engine regulation tier 3. The water-emulsified diesel could be used in the light-duty small diesel engine without modifications. The result shows that the net diesel fuel consumption and the exhaust gas temperature decreased with increasing water content of fuels over the investigated loading range.

Performance produced by DWE 10\% and 15\% will been reduce Power, and Torque at each RPM. In detail, DWE 10\% has better results than the DWE 15\%. In the NOx emission test results, the use of water/biodiesel emulsified fuels 10\% and $15 \%$ can reduce NOx emissions.
\end{abstract}

Keywords- biodiesel, B20, water/biosolar emulsion 10\%, water/biosolar emulsion 15\%, engine performance

\section{INTRODUCTION}

The use of biodiesel fuel is expected to contribute to the reduction of global warming, M. Lapuerta, O. Armas, J. RodríguezFernández [2003]. Also, using a blend of biodiesel fuel as an alternative to pure fossil fuels has a number of other advantages: it is less polluting, cost effective, it has higher lubricity and a higher flash point, and it can be used in Diesel engines with minimal, or no, modifications, M. Lapuerta, J. Rodríguez-Fernández, O. Armas [2003], L.C. Meher, D. Vidya Sagar, S.N. Naik [2006], R.O. Dunn [2009], J. Hill, E. Nelson, D. Tilman, S. Polasky, D.Tiffany [2006], J. Tickell, K. Roman [2003]. According to the U.S. Environmental Protection Agency Tier I and Tier II standards (see US Environmental Protection Agency [2014] for details), fatty acid methyl ester (FAME) biodiesel types produced over the last decade pass the testing requirements for health effects.

The use of water-diesel emulsions has been around since 1970's, A. Lif, K. Holmberg [2006] and some researchers have also reported that the use of a small amount of water in the biodiesel blends induces a trade-off between reductions of PM, $\mathrm{CO}$ and also reduction in NOx contrary to using straight biodiesel that lead to increased NOx emissions, S.-H. Liu, Y.-C. Lin, K.-H. Hsu [2012], Y.C. Chang, W.J. Lee, H.H. Yang, L.C. Wang, J.H. Lu, Y.I. Tsai, et al. [2014], Y.-C. Chang, W.J. Lee, S.-L. Lin, L.-C [2013]. According to Alahmer [2013], the presence of small amounts of water in the fuel has a significant effect on the physical and chemical kinetics of combustion, where by it reduces combustion temperatures and providing $\mathrm{OH}$ radicals in the combustion environment. The $\mathrm{OH}$ radicals act to control $\mathrm{NOx}$ formation and to oxidize soot resulting in reducing both NOx and PM emissions. In addition, the micro-explosion action of water droplets has been proposed as the major mechanism that results in a better turbulence of fuel and oxidants, causing more complete combustion and consequently a significant reduction of criteria pollutants emissions, when using water-containing fuels. Frequently, surfactants are added in the emulsions to stabilize the water-diesel mixtures in order to minimize the coalescence mechanism of the water phase as well as reducing the surface tension between the diesel and water phases, M. Huo, S. Lin, H. Liu, C.-f.F. Lee [2014]. In a study of stability of water diesel emulsions, Ghannam and Selim [2009] determined that: (a) surfactants are essential for stability of water-diesel emulsions (b) the stability of water-diesel emulsions decreased with an increase in water fractions (c) at higher fractions of water, more surfactants should be employed as well as higher mixing rates (d) the density of water-diesel emulsions increase with increase in water fractions.

As mentioned earlier water addition is one of the techniques of emission control in the diesel engine. Different ways can be used to introduce water into the engine and they include (i) mixing water in form of steam with air at inlet, (ii) injecting water and diesel coincidentally (iii) forming water and diesel emulsions which can be stabilized or not be stabilized with surfactants or co-solvents such as natural organic enzymes, W. Yuan, A.C. Hansen, Q. Zhang [2003]. A comparison of water-diesel emulsion and timed injection of water into the intake manifold of a diesel engine was done by Subramanian [2011] and the performance in controlling NOx and smoke emissions was evaluated. The emulsion method was more 
effective in controlling NOx and smoke, while the injection method worked well for $\mathrm{CO}$ and $\mathrm{HC}$ emissions with better diffusion combustion phase, Beny Cahyono at.al, [2017].

In this review work, the focus will be on water emulsions. Water emulsions result in micro-explosion phenomena, where by during combustion the overall boiling temperature is controlled by the diesel which is the less volatile of the two, M. Huo, S. Lin, H. Liu, C.-f.F. Lee [2014], water evaporates faster than diesel due to differences in boiling points, Hagos FY, Tan IM [2011]. When water reaches its superheated stage earlier than diesel, it creates a vapor expansion break up causing micro-explosion whereby droplets disintegrate into smaller droplets in a kind of secondary atomization. This secondary atomization enhances air and fuel mixing, which is advantageous in emission reduction, T. Kadota, H. Yamasaki [2002]. According to Ithnin et. al. [2014] water in diesel emulsions can reduce NOx and PM concurrently as well as induce improved combustion efficiency without engine modifications. What is more is that water presence increases amount of $\mathrm{OH}$ radicals, which act to reduce soot formation by oxidizing the soot precursors. The following paragraphs illustrate the results of various studies on the use of water addition technique in engines. According to Attia et al. [2014], the finer the emulsion droplets, the greater $\mathrm{HC}$ and $\mathrm{CO}$ reductions with even better engine performances, while larger droplets lead to comparatively greater reduction in NOx emissions.

\section{METHODS}

To find out the effect of using emulsion fuel on engine performance, the research was carried out using the experimental method. This experimental process begins with the preparation of biosolar/water emulsion fuel, the engine set up along with supporting tools.

(A) Biodiesel Production

In the process of making biodiesel, it requires necessary tools to be used. The tools that used in this experiment, must be laboratory grade, consists of transesterification equipment;
a. Heater
b. Thermometer
c. measuring cylinder
d. glass cylinder
e. stirrer
a. Crude palm oil
b. water
c. $\mathrm{KOH}$
d. Methanol

As for the materials needed for this experiment include;

The first process is heating of crude palm oil. The oil is heated to a temperature of about 55 to 65 degrees, followed by the addition of $\mathrm{KOH}$. Heating each session with a volume of $750 \mathrm{~mL}$, then it is added by a mixture of water $400 \mathrm{ML}$ and $\mathrm{KOH} 4 \mathrm{gram}$. Followed by mixing methoxide and crude palm oil for 1 hour.

After it is well-mixed, the next is settling process. This process is used to separate biodiesel and glycerol. Settling process takes 8 hours. The glycerol will be separated, the next is biodiesel washing process using water liquids. After the washing process, the final step is the drying process. This step is to ensure that no water exists in biodiesel that has been cleared during the manufacturing process.

(B) Diesel Water Emulsion Production

The composition of diesel water emulsion of biodiesel palm oil and water greatly affect the fuel produced. The Process of Stirring B20 and water used at the experimental process. The equipment and materials consists of

- Biodiesel Palm Oil

- $\quad$ Span 80

- $\quad$ Tween 80

- Aquades

- Mixer

- Cylinder Glass

In this experiment there are two variables for diesel water emulsion, there are DWE $10 \%$ and DWE $15 \%$. The composition DWE $10 \%$ is $84 \mathrm{ml}$ of B20, $10 \mathrm{ml}$ water and 6\% surfactants and DWE $15 \%$ is $79 \mathrm{ml}$ of B20, $15 \mathrm{ml}$ water, and $6 \%$ surfactants. The composition surfactants are $3 \mathrm{ml}$ of Span 80 and 3ml Tween 80 using syringes because the viscosity of surfactants was high. After that all the ingredients are put in place and then mixed all. The mixing process of B20 + Water + Surfactant using mixer, stirring time takes time until this solution does not foam again during stirring process. After mixing process, water diesel emulsion is produced. 


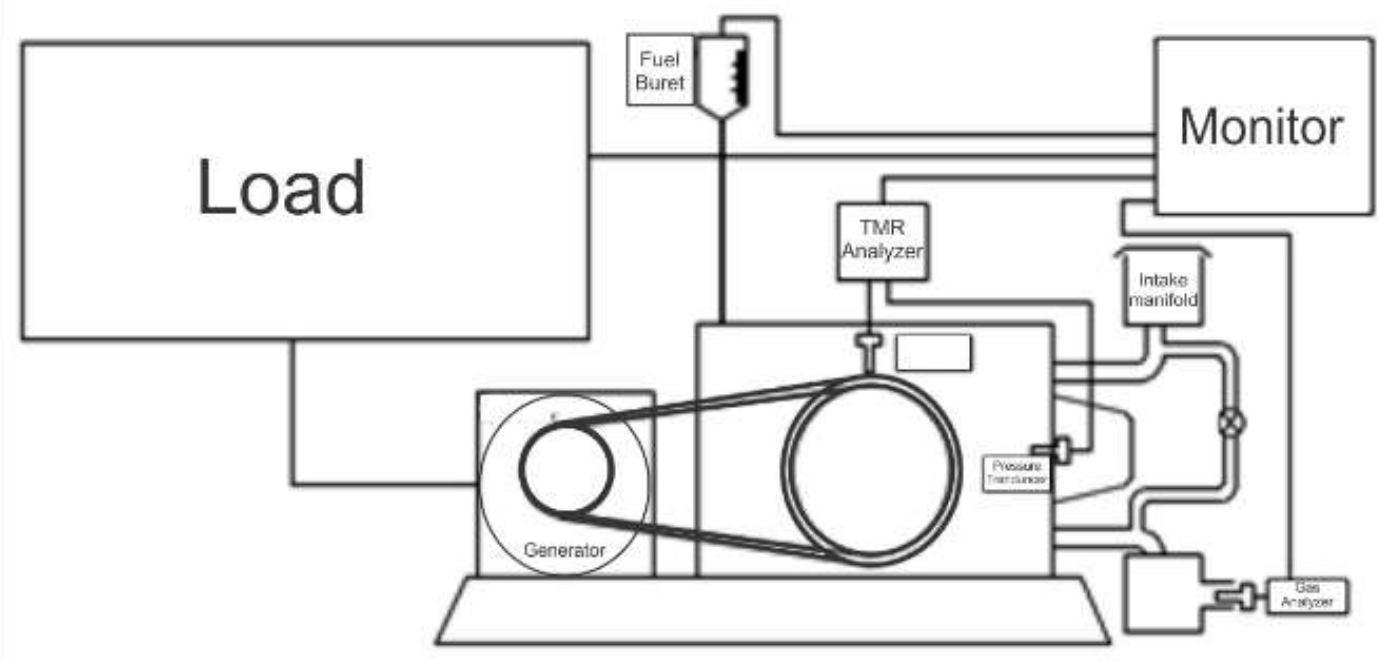

Figure 1 schematic of engine test

(C) Engine Set - up

Engine SET UP process is installation of test equipment such as Electric Dynamo to know the Performance and Combustion Analysis. In this combustion analysis test there are several sensors installed, including Vibrasindo TMR-Card Board \& TMR- Crank Angle-Rotary Encoder Hardware on diesel engine YANMAR type TF 85 MH-di. Then performed the process of installation software / tool called TMR Instruments to display the combustion process on the computer screen to find out the combustion process. And the third is Exhaust Gas Analyzer to know the level of NOx emission. In this stage, it is expected that all equipment and materials are ready so that it can simplify the process of data retrieval.

\section{Engine Performa test}

The performance test was carried out to determine the power, torque and SFOC of a diesel motor using biodiesel fuel and water/biosolar fuel that had been provided previously, the Performance Test was carried out with various variables.

Fix Variabel

$>$ Emulsion fuel $10 \%$ \& $15 \%$

$>$ engine RPM

use maximum load for several engine turns, 1800, 1900, 2000, 2100, 2200 RPM

$>$ independent variable

Variable load

\section{Nox emission test}

The performance test was carried out to determine the NOx content of diesel motor emissions using biodiesel water emulsion. The Performance Test will be carried out with a different of fuel compositions.

$>$ Fix Variabel

○ Water/biosolar emulsion $10 \% \& 15 \%$

○ RPM

$>$ independent variable Variable load

Test methods on emission testing and combustion processes, RPM points and loads follow procedures in the Marpol Annex VI IMO rules. The type of test chosen is the E2 type test cycle, the test method for type E2 is as seen in table 3.2 below:

Table 1. MARPOL Annex VI, Appendix II Test Cycle

\begin{tabular}{|l|l|l|l|l|l|}
\hline \multirow{2}{*}{$\begin{array}{l}\text { Test } \\
\text { Cycle } \\
\text { Type E2 }\end{array}$} & Speed & $100 \%$ & $100 \%$ & $100 \%$ & $100 \%$ \\
\cline { 2 - 6 } & Power & $100 \%$ & $75 \%$ & $50 \%$ & $25 \%$ \\
\cline { 2 - 6 } & $\begin{array}{l}\text { Weight } \\
\text { Factor }\end{array}$ & 0.2 & 0.5 & 0.15 & 0.15 \\
\hline
\end{tabular}




\section{Engine Performance}

\section{RESULT AND DISCUSSION}

To find out the effect of biosolar-water emulsion improvement, in this research an engine test bed was tested with 4 variations of fuel, namely, solar dex (dexlite), B20, water/biosolar emulsion $10 \%$ and water/biosolar emulsion $15 \%$.

\subsection{Effect of Biosolar-water emulsion on Brake Specific Fuel Consumption}

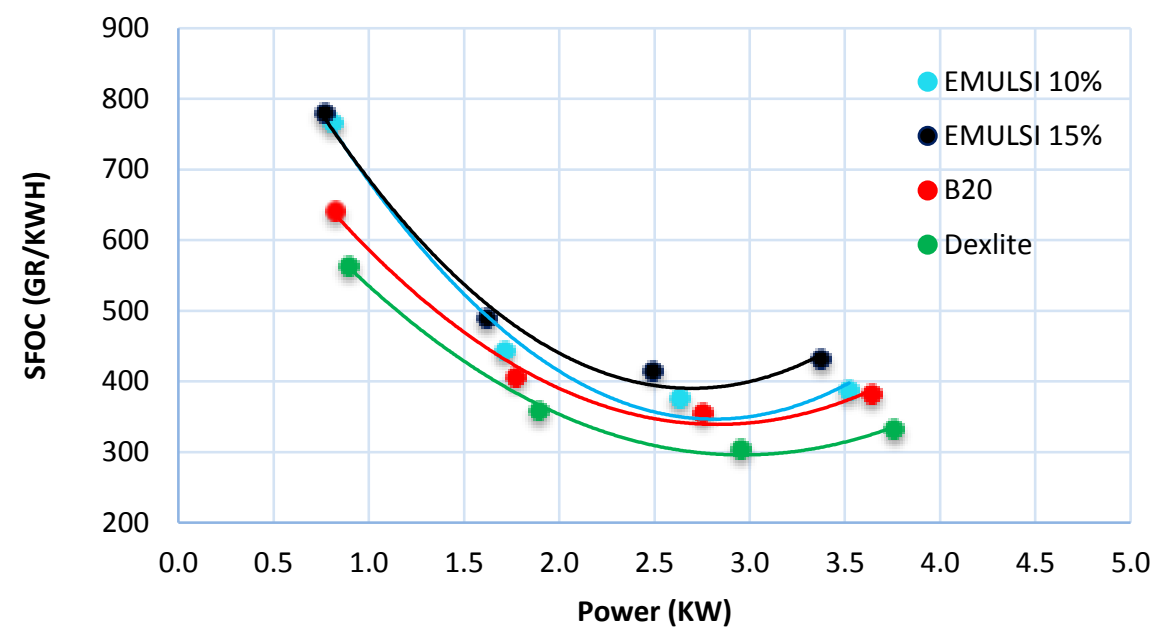

Figure 2. Effect of biosolar-water emulsion to specific fuel consumption

To determine brake-specific fuel consumption (BSFC) in steady working conditions (constant speed, constant torque), the consumption period of a certain amount of fuel was measured and BSFC was calculated. A scale and time were used to measure fuel consumption. Figure 2 show the variation in BSFC of an engine using solar dex, biosolar, water emulsion $10 \%$ and water emulsion $15 \%$ fuel with respect to engine speed.

Normally, BSFC is a function of engine speed. BSFC decreases as engine speed increases; it reaches a minimum and increases at high speeds. Fuel consumption increases at high speed because of greater of friction losses. At low engine speeds, the longer time per cycle allows for greater heat loss and fuel consumption increases (Willard, 2004). The friction loss of a rotation engine occurs at high speed, causing fuel consumption to increase. BSFC is even affected by the fuel equivalence ratio.

BSFC for different fuels are compared in Figure 1. BSFC is a function of heating value of fuel, ignition delay, air-fuel ratio, engine load and speed. The BSFC rises as the engine speed increases. It is mostly due to the number of working cycles in a specific period of time at high engine speed (Heywood, 1988; Ferguson \& Kirkpatrick, 2001). In Figure 1 BSFC of water emulsion $15 \%$ is the highest followed by water emulsion $10 \%$. It is well known that heating value of fuel affects the BSFC of an engine. The lower energy content of biosolar-water emulsion fuel causes some increment in BSFC of the engine when it is used without any modification. The increment mainly depends on the percentage of water. The heating value of water is less than the values of solar and biosolar. More fuel water emulsion is needed to produce same power at one operating conditions due to its lower heating value in comparison to solar.

Based on the graph above, can be seen that solar Dexlite have lowest SFOC diesel engine which is $300.6 \mathrm{gr} / \mathrm{kWh}$. Adding biodiesel to the engine will increase fuel consumption, in this study using B20 fuel will produces SFOC of $349.7 \mathrm{gr} / \mathrm{kWh}$. When B20-water emulsion 10\% water have SFOC $365.4 \mathrm{gr} / \mathrm{kWh}$. B20 - water emulsion 15\% fuel, have SFOC $410.4 \mathrm{gr} /$ kWh.

\subsection{Effect of biosolar-water emulsion on Brake Power}

The evaluation of engine power performance focused on the brake power based on variations in engine speed. The engine power performance results from the solar dex, biosolar (B20), WDE 10\% and WDE 15\% as shown bellow 


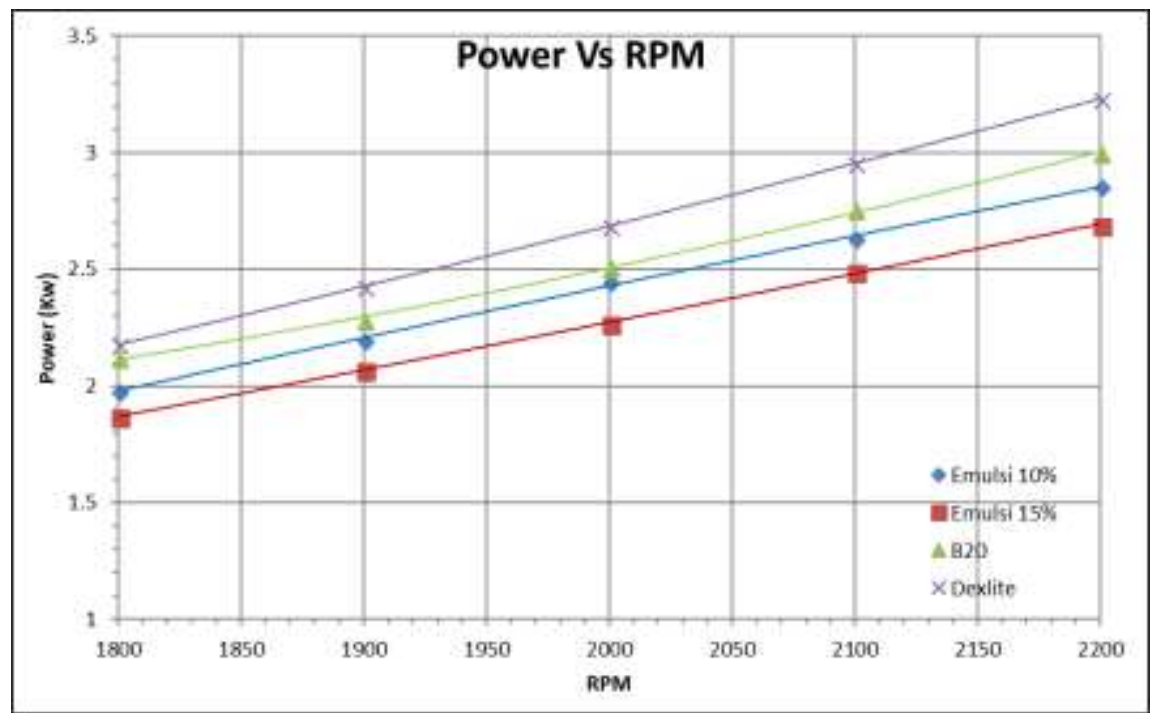

Figure 3. Effect of biosolar/water emulsion on engine power at different engine speed

The brake power performance of the biosolar fuel and biosolar/water emulsion fuel are shown in Figure. The brake power represents the power available at the flywheel after accounting for all friction and attachment losses, as well as the acceleration of the crank train inertia for the brake torque. In the diesel engine, the highest brake power was determined at an engine speed of $2200 \mathrm{rpm}$. In the biosolar/water emulsion fuel, from $1800 \mathrm{rpm}$ to $2200 \mathrm{rpm}$, increasing engine speed increased the brake power. In biosolar fuel and biosolar/water emulsion, the highest brake power was determined at an engine speed of $2200 \mathrm{rpm}$.

The increasing engine speed can increase the deviation point or deviation percentage of the brake power of the biosolar fuel compared to the water/biosolar emulsion. Thus, increasing engine speed can increase the percentage deviation of brake power of the water/biosolar emulsion and biosolar fuel. Power generated from the full-load showed an increase with increasing engine speed. Power generated by the biosolar fuel is $2.1 \mathrm{kw}$ at $1,800 \mathrm{rpm}$ and has increased up to $3 \mathrm{~kW}$ at 2,200 $\mathrm{rpm}$. In this condition, engines have optimum operations at 2,200 rpm; after the round of 2,200 rpm, the engine power will decrease.

\subsection{Effect of water/biosolar emulsion on engine brake torque}

Engine torque is the main parameter for evaluated engine performance. In this test, the engine was run by using full load. The engine torque performance results of the different fuels, namely solar dex, biosloar, water/biosolar emulsion $10 \%$ and water/biosolar emulsion $15 \%$ are shown in Error! Reference source not found. The indicated torque represents the thermodynamic work transferred from the gas to the piston converted via geometry to torque applied to the crankshaft.

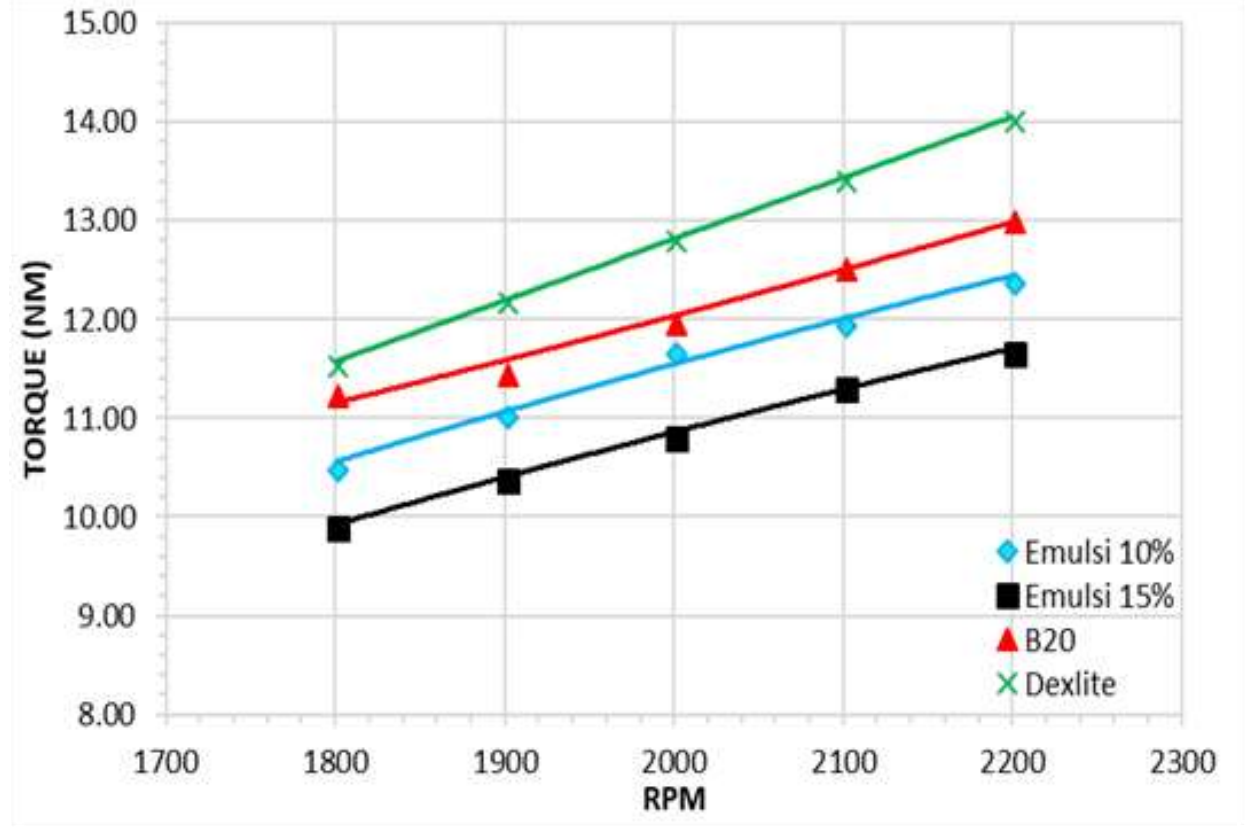


Figure Error! No text of specified style in document.. Effect of water/biosolar emulsion on engine torque at different

engine speed

At low engine speeds and low load, the higher heating value of solar dexlite and biosolar is responsible for the higher torque obtained for the fuel blend. For high engine speeds, the faster flame velocity (Amaral 2000) makes solar dexlite produce higher torque than the biosolar. At high engine speeds, there is less time available to complete combustion in an engine cycle, and a faster flame velocity is required. Advancing ignition timing increases combustion chamber pressure and temperature, as well as the flame speed. The flame speed is influenced by several parameters, such as air-fuel mixture, mixture temperature, and pressure (Thusdré 1998).

This study showed that the conversion of a biosolar into a water/biosolar fuel decreased the engine's torque performance. This was caused by the different properties of biosolar and water/biosolar emulsion fuels. Biosolar is composed of fuels that have higher low heating value than water/biosolar emulsion.

\section{4 effect of water/biosolar emulsion on engine combustion pressure}

Combustion process is the process of converting chemical energy into heat energy, using fuels and oxidizing agents. Fuel type there are two types of internal and external combustion. The difference between diesel-fueled engines and emulsions is induction diesel fuel in fuel is significantly clean.

In the process of obtaining data for the result of this combustion process, the retrieval point is determined based on IMO MARPOL Annex VI rules on test cycle for NOx emission testing. The test cycle arranged by MARPOL Annex VI states that testing is carried out at 25,50\%,75\% and $100 \%$ load at $100 \%$ RPM t. The data obtained from the process of combustion based on test cycle emission NOx is to analyze how much influence might change the combustion process towards the decrease of NOx content. The determination of this data retrieval points is obtained from the process of calculating the performance.

From the combustion process, it will be analyzed about combustion pressure chart, rate of heat release and ignition delay. The result of the combustion process is obtained through experimental activities. The result of the combustion process is as follows;

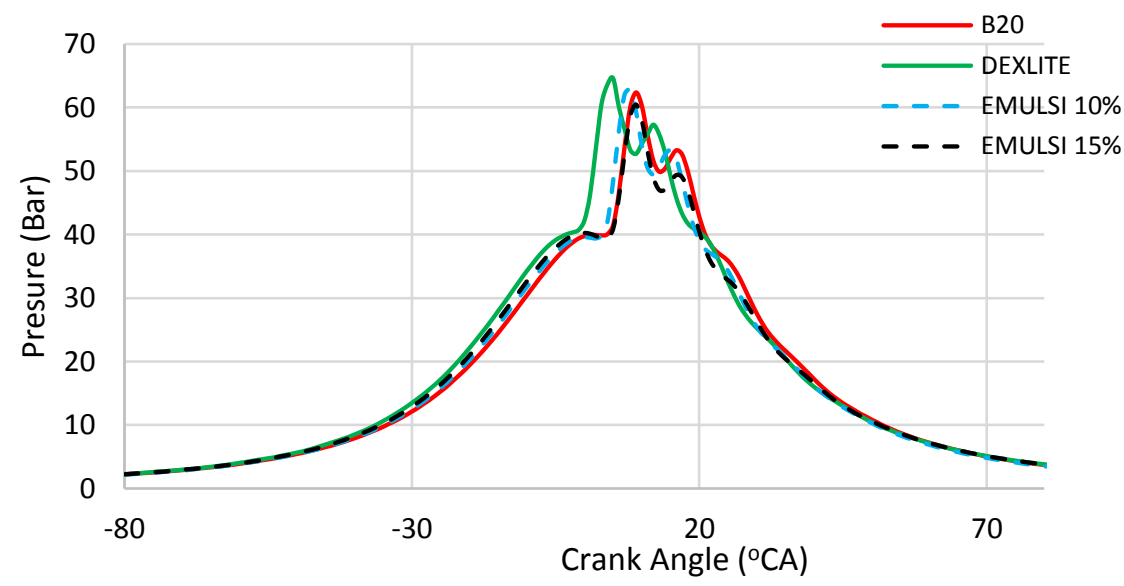

Figure 5. combustion pressure at 100\% RPM and load 50\% 
Figure above shown a comparison graph of combustion pressure at each degree of crank angle occurring at $100 \%$ RPM with load 50\%. maximum combustion pressure chart of Dexlite fuel, B20, DWE 10\% and DWE 15\%. Graph of the experimental process, the use of fuel b20 will be increase the peak pressure in the combustion process. This is in line with the reference and some theories from previous studies that explain that the addition of water to the fuel content can lead to higher combustion pressure. This is because the water content contained in the emulsion fuel affects the conditions when injection of fuel into the combustion chamber. This is caused by the content of water containing lots of oxygen (O2). Oxygen is a major component in the combustion process, increased oxygen in the combustion chamber causes pressure on the combustion chamber increases

$\mathrm{NO}_{\mathrm{x}}$ Emission Test Results

One of problem in the use of diesel engines is the production of NOx from combustion. NOx can be formed from oxygen and free nitrogen at very high combustion chamber temperatures. In this study $\mathrm{NO}_{\mathrm{x}}$ measurements were carried out referring to MARPOL Annex VI. Issued by the International Maritime Organization(IMO) discusses standards or $\mathrm{NO}_{\mathrm{x}}$ emission thresholds that are permitted from diesel engine exhaust emissions.

In this study the use of B20 fuel in diesel engines showed a significantly increase of $\mathrm{NO}_{\mathrm{x}}$ produced when the engine was running at a low load, however at high loads $\mathrm{NO}_{\mathrm{x}}$ produced is almost the same for all fuel's. At low load testing, the addition of water in biosolar fuel significantly reduces the emission $\mathrm{NO}_{\mathrm{x}}$ produced.

The use of water in diesel engine fuel has a number of benefits that have been found, that water has an effect on reducing peak fire temperatures and reducing $\mathrm{NO}_{\mathrm{x}}$ emissions [16].

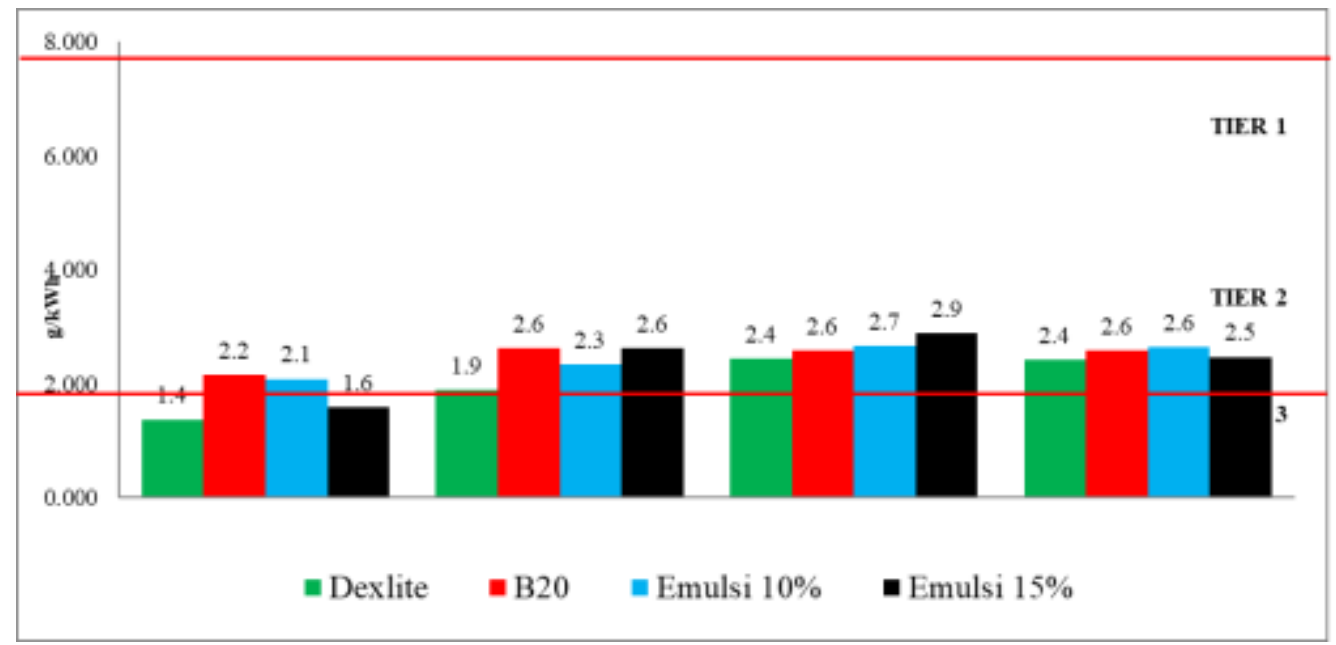

Figure 6. The effect of water addition on biosolar fuel on $\mathrm{NO}_{\mathrm{x}}$ emission, at 100\% RPM and different load.

Figure 6 Bar chart of NOx content at 100\% RPM and load on diesel motor with Dexlite fuel, B20, DWE 10\% and DWE $15 \%$. The addition of water on the $\mathrm{B} 20$ fuel is intended to reduce the level of $\mathrm{NO}_{\mathrm{x}}$ emissions.

From the result, the emission of $\mathrm{NO}_{\mathrm{x}}$ emitted by Dexlite are $1.4 \mathrm{~g} / \mathrm{kWh}, 1.9 \mathrm{~g} / \mathrm{kWh}, 2.4 \mathrm{~g} / \mathrm{kWh}$ and $2.4 \mathrm{~g} / \mathrm{kWh}$, respectively. Under $25 \%$ load, $\mathrm{NO}_{\mathrm{x}}$ emissions are included in the TIER 3 qualification, but at $50 \%$ to $100 \%$ loads included in the TIER 2 qualification, the newest rule issued by IMO for the latest machine.

In B20 fuel, the resulting $\mathrm{NO}_{\mathrm{x}}$ emissions are $2.2 \mathrm{~g} / \mathrm{kWh}, 2.6 \mathrm{~g} / \mathrm{kWh}, 2.6 \mathrm{~g} / \mathrm{kWh}$ and $2.6 \mathrm{~g} / \mathrm{kWh}$, respectively. At a load of $25 \%$ the use of B20 increases the $\mathrm{NO}_{\mathrm{x}}$ more significantly compared to when the engine works on heavy loads. As a result of the use of B20 fuel, NOx emissions are included in the TIER 2 qualification.

In DWE 10\%, the emission of $\mathrm{NO}_{\mathrm{x}}$ emissions are $2.1 \mathrm{~g} / \mathrm{kWh}, 2.3 \mathrm{~g} / \mathrm{kWh}, 2.7 \mathrm{~g} / \mathrm{kWh}$ and $2.6 \mathrm{~g} / \mathrm{kWh}$, respectively. under all load conditions, emission reductions were $0.1 \mathrm{gr} / \mathrm{kWh}, 0.3 \mathrm{gr} / \mathrm{kWh}$ compared to B20 fuel consumption respectively. At $75 \%$ load increased $\mathrm{NO}_{\mathrm{x}}$ emissions by $0.1 \mathrm{~g} / \mathrm{kWh}$. While at $100 \%$ load there is no increase or decrease of NOx emission. As a result of $10 \%$ emulsion fuel usage, NOx emissions are included in TIER 2 qualification.

While on DWE $15 \%$ the emission of NOx are $1.6 \mathrm{~g} / \mathrm{kWh}, 2.6 \mathrm{~g} / \mathrm{kWh}, 2.9 \mathrm{~g} / \mathrm{kWh}$ and $2.5 \mathrm{~g} / \mathrm{kWh}$. At the condition of $15 \%$ load there is an emission reduction of $0.5 \mathrm{gr} / \mathrm{kWh}$ compared to the use of fuel B20. However, at the $75 \%$ load NOx emissions produced higher than the use of fuel B20, ie $0.3 \mathrm{gr} / \mathrm{kWh}$ of fuel use B20. However, the result of DWE $15 \%$ at $25 \%$ load is able to fulfill the requirement of TIER3 that is at maximum $\mathrm{NO}_{\mathrm{x}}$ level $1.6 \mathrm{gr} / \mathrm{kWh}$ on motor with spin above 2000 RPM

It can be concluded that the addition of water can lower the $\mathrm{NO}_{\mathrm{x}}$ level at low load, but at $50 \%$ load $\mathrm{NO}_{\mathrm{x}}$ increase, but $\mathrm{NO}_{\mathrm{x}}$ slightly increase. The result of emission of $\mathrm{NO}_{\mathrm{x}}$ emulsion fuel $15 \%$ load from diesel motor is able to meet the TIER 3 classification of the IMO rule in MARPOL Annex VI which regulates air pollution.

Reduced peak pressure, longer ignition delay and lower rate of heat release cause the resulting emission of NOx is smaller than the original state. The significant increase of $\mathrm{NO}_{\mathrm{x}}$ emissions due to the incomplete combustion process of diesel 
engine. The increase of heat release on DWE $10 \%$ and $15 \%$ is not matched by the thermal efficiency of the combustion process. This is actually already predictable if we look from the previous graph of combustion pressure and rate of heat release. the heat release and pressure charts show a steady decrease in pressure and heat release increase on each fuel.

\section{CONCLUSION}

According to the results and discussion, the water-emulsified diesel could be used in the light-duty small diesel engine without modifications. The result shows that the net diesel fuel consumption and the exhaust gas temperature decreased with increasing water content of fuels over the investigated loading range.

Performance produced by DWE $10 \%$ and $15 \%$ will been reduce Power, and Torque at each RPM. In detail, DWE $10 \%$ has better results than the DWE 15\%. In the $\mathrm{NO}_{\mathrm{x}}$ emission test results, the use of water/biodiesel emulsified fuels $10 \%$ and $15 \%$ can reduce $\mathrm{NO}_{\mathrm{x}}$ emissions.

In the combustion process analysis, the use of water in DWE may result in lower peak combustion pressure. Emulsion fuel also causes the ignition timing to be slower. Heat release on the emulsion material is lower in the low load, but at the maximum load the DWE $10 \%$ \& $15 \%$ heat release has increased, but even though the heat release is high, the resulting power is smaller due to the low emulsion fuel thermal efficiency

\section{REFERENCES}

- A. Alahmer, "Influence of using emulsified diesel fuel on the performance and pollutants emitted from diesel engine",Energy Convers Manage, 73 (2013), pp. 361-369

- A.M.A. Attia, A.R. Kulchitskiy, "Influence of the structure of water-in-fuel emulsion on diesel engine performance", Fuel, 116 (2014), pp. 703-708

- A.M. Ithnin, H. Noge, H. Abdul Kadir, W. Jazair, An overview of utilizing water-in-diesel emulsion fuel in diesel engine and its potential research study", J Energy Inst, 87 (2014), pp. 273-288

- A. Lif, K. Holmberg "Water-in-diesel emulsions and related systems", Adv Colloid Interface, 123 (2006), pp. 231-239

- Beny Cahyono, Aguk Zuhdi Muhammad Fathallah, Nauval Pahlevi, "Effect of Water Fuel Emulsion on Performance and NOx Emissions of Diesel Engine", International Journal of Marine Engineering Innovation and Research (2017)

- J. Hill, E. Nelson, D. Tilman, S. Polasky, D.Tiffany,"Environmental, economic, and energetic costs and benefits of biodiesel and ethanol biofuels", Proc Natl Acad Sci, 103 (2006), pp. 1120611210, 10.1073/pnas.0604600103

- J. Tickell, K. Roman, "From the fryer to the fuel tank: the complete guide to using vegetable oil as an alternative fuel", Joshua Tickell Media Productions, New Orleans, LA (2003)

- Hagos FY, Tan IM. "Water-in-diesel emulsion and its micro-explosion phenomenon-review". Communication Software and Networks (ICCSN), 2011 IEEE 3rd International Conference on: IEEE; 2011. p. 314-8.

- K. Subramanian. "A comparison of water-diesel emulsion and timed injection of water into the intake manifold of a diesel engine for simultaneous control of NO and smoke emissions", Energy Convers Manage, 52 (2011), pp. $849-857$

- M. T. Ghannam \&M. Y. E. Selim, "Stability Behavior of Water-in-Diesel Fuel Emulsion”,Pages 396411 | Published online: 11 Mar (2009)

- M. Huo, S. Lin, H. Liu, C.-f.F. Lee. "Study on the spray and combustion characteristics of water-emulsified diesel Fuel”, 123 (2014), pp. 218-229

- M. Lapuerta, O. Armas, J. Rodríguez-Fernández "Effect of biodiesel fuels on diesel engine emissions" Prog Energy Combust Sci, 34 (2008), pp. 198-223, 10.1016/j.pecs.2007.07.001

- M. Lapuerta, J. Rodríguez-Fernández, O. Armas; "Correlation for the estimation of the density of fatty acid esters fuels and its implications. A proposed biodiesel cetane index", Chem Phys Lipids, 163 (2010), pp. 720-727, 10.1016/j.chemphyslip.2010.06.004

- L.C. Meher, D. Vidya Sagar, S.N. Naik, "Technical aspects of biodiesel production by transesterificationa review", Renew Sustain Energy Rev, 10 (2006), pp. 248-268, 10.1016/j.rser.2004.09.002

- R.O. Dunn; "Cold-flow properties of soybean oil fatty acid monoalkyl ester admixtures Energy Fuels", 23 (2009), pp. 4082-4091, 10.1021/ef9002582

- S.-H. Liu, Y.-C. Lin, K.-H. Hsu, "Emissions of regulated pollutants and PAHs from waste-cooking-oil biodieselfuelled heavy-duty diesel engine with catalyzer",Aerosol Air Qual Res (2012), p. 12

- T. Kadota, H. Yamasaki, "Recent advances in the combustion of water fuel emulsion", Prog Energy Combust Sci, 28 (2002), pp. 385-404

- US Department of Energy: Energy Efficiency and Renewable Energy. Biodiesel Blends. $<$ http://www.afdc.energy.gov/fuels/biodiesel_blends.html>; n.d. [accessed October 13, 2015].

- US Environmental Protection Agency. <http://www.epa.gov/>; 2014 [accessed November 15, 2014]. 
- W. Yuan, A.C. Hansen, Q. Zhang, "Predicting the physical properties of biodiesel for combustion modeling", Trans ASAE, 46 (2003), pp. 1487-1493, 10.13031/2013.15631

- Y.C. Chang, W.J. Lee, H.H. Yang, L.C. Wang, J.H. Lu, Y.I. Tsai, et.al., "Reducing emissions of persistent organic pollutants from a diesel engine by fueling with water-containing butanol diesel blends",Environ Sci Technol, 48 (2014), pp. 6010-6018

- Y.-C. Chang, W.-J. Lee, S.-L. Lin, L.-C. ,"WangGreen energy: water-containing acetone-butanol-ethanol diesel blends fueled in diesel engines", Appl Energy, 109 (2013), pp. 182-191 